\title{
From roots to vents: magmatic fluids episodically flush oceanic hydrothermal systems
}

\section{S. FOX ${ }^{\prime *}$, Y. KATZIR', W. BACH${ }^{2}$, L. SCHLICHT ${ }^{2}$ AND J. GLESSNER}

'Ben Gurion University of the Negev, Be'er Sheva, Israel (*correspondence: sthephen@post.bgu.ac.il)

2Faculty of Geoscience,University of Bremen, Germany ${ }^{3}$ Interdisciplinary Center for Plasma Mass Spectrometry, University of California, Davis, CA 95616, USA

Circulation of seawater at oceanic spreading centers extracts heat, drives rock alteration, and transport metals up to shallower levels of the crust where they precipitate in contact with fresh seawater and may form ore deposits. However, a key factor of metal mobilization in seafloor hydrothermal systems is often overlooked: the role of magmatic fluids derived from exsolving volatiles during the crystallization of the lower crust. Here, we study the hydrothermal imprint preserved in the Troodos ophiolite, Cyprus, which comprises an intact section of a Cretaceous suprasubduction zone oceanic crust. In-situ ${ }^{87} \mathrm{Sr}_{/}^{86} \mathrm{Sr}$ ratios and REE patterns of distinct domains in epidote, a common hydrothermal mineral throughout the crust, are used to track magmatic fluid input and flow. Oscillatory zoned epidote from fossil upflow zones yield alternating ${ }^{87} \mathrm{Sr} /{ }^{86} \mathrm{Sr}$ ratios of 0.704 and 0.706 , typical of magmatic fluids and modified Cretaceous seawater, respectively. REE patterns of epidote growth zones are highly variable and strongly coupled to the $\mathrm{Sr}$ isotope ratios. Each of the analyzed epidote crystal domains is characterized by any of three Sr isotopeREE signatures - indicating sequential flow of magmatic-, rock-buffered and seawater-derived fluids. Epidote thus records episodic fluxing of magmatic fluids through the upflow zone, which supplies metals to sub-seafloor basalt-hosted Volcanogenic Massive Sulfide (VMS) deposits. 